H. Rickman (ed.), Transactions of the International Astronomical Union, Vol. XXIVB, 247-249. (C)2001 IAU. Printed in the United States of America.

\title{
COMMISSION 38: EXCHANGE OF ASTRONOMERS (ECHANGE DES ASTRONOMES)
}

\section{PRESIDENT: Morton Roberts}

VICE-PRESIDENT: Richard M. West

ORG ANIZING COMMITTEE: D. Chitre, J. Ducati, H. Jørgensen, G. Krishna, M. Morimoto, C. Tolbert, S. Ye

\section{Report of Business Meeting at 11:00, 14 August 2000}

Members present: Vice-president, S.-H. Ye, J. Zhao

Agenda:

1. Travel Grants Awarded

2. Review of Guidelines for Travel Grants

3. Merging of Commissions 38 and 46

4. Officers for Program Group on the Exchange of Astronomers

5. Any other business

Substituting for the President, who was unable to come to Manchester, the Vice-President opened the meeting, welcoming those who attended. The agenda was adopted.

\section{Grants Awarded}

The Vice-President reported that during the triennium the Commission business was carried out by the President and himself through e-mail, greatly facilitating the application and granting procedure. All arrangements for the transfer of funds etc. by the IAU Secretariat in Paris were likewise conducted via e-mail.

The Vice-President pointed out that the cooperation among all parties had been excellent and he expressed his sincere thanks to Dr. Morton Roberts and Mme. Monique Orine of the IAU Secretariat.

Thirty-five grants were made during the triennium October 1, 1996 - September 30, 1999. These are individually listed in "Reports on Astronomy", Volume XXIV A. There are 20 different countries of origin and 16 host countries represented in that period. 2000:

Nine additional grants were made in the period from October 1, 1999 through July 20,

\begin{tabular}{lll}
\hline Name & Origin & Destination \\
\hline A. Arellano & Mexico City (Mexico) & Bangalore (India) \\
P. Rosenzweig & Merida (Venezuela) & Bloomington (Indiana, USA) \\
J. Sperauskas & Klnius (Lithuania) & Tucson (Arizona, USA) \\
A. Kazlauskas & Vilnius (Lithuania) & Tucson (Arizona, USA) \\
V.A. Brumberg & St. Petersburg (Russia) & Paris (France) \\
B. Efremova & Sofia (Bulgaria) & Mexico City (Mexico) \\
F.J. Esteban & Madrid (Spain) & Hamburg (Germany) \\
J. Stil & Toronto (Canada) & Pune (India) \\
J.F.V. Marquez & Havana (Cuba) & Mexico City (Mexico) \\
\hline
\end{tabular}


The expenditures for travel grants during the past years were:

\begin{tabular}{ll}
\hline Year & Swiss Francs (CHF) \\
\hline 1994 & 17,456 \\
1995 & 15,762 \\
1996 & 17,481 \\
1997 & 27,729 \\
1998 & 12,825 \\
1999 & 28,124 \\
2000 & $(25,000$ proposed) \\
\hline
\end{tabular}

The members present agreed that there is a clear and continuing need for support within this scheme and that it is important that support from the IAU is available, at least at the foreseen level.

\section{Guidelines for Travel Grants}

The Guidelines are available on the web at http://www.iau.org/edu.html (click on Commission 38) or at http://ww .eso.org/iaucom38. Most issues of the IAU Information Bulletin also carry the Guidelines. It is the impression of the President and Vice-President that these Guidelines work well and, as long as they are handled flexibly, there is no need for major changes at this moment.

However, a number of questions have come up during the past triennium that should be discussed.

- The Guidelines request at least a three (3) month visit. However, applicants frequently want a lesser time, sometimes only a few weeks. Should this criterion be relaxed? The members present agreed that it would be reasonable to reduce the minimum time to two (2) months, but that shorter visits, because of their overall impact, should not be supported.

- Widely different fare systems are available, depending on the trajectory, the time of the year, pre-booking, etc. Should there be a limit on the size of the grant? The members present thought that it would be unwise to fix such a limit, but that emphasis must be made on the use of cheap tickets. Applicants must endeavour to obtain the fullest possible information about existing reduction schemes and should book and purchase the tickets sufficiently ahead of their travel in order to ensure the availability of reduced fares.

- Some requests have been received from more senior scientists who have already travelled extensively. While formally fulfilling the rules of the scheme, does such support also conform with its spirit? Would it be reasonable to fix an upper limit to such support? The members present recommended that at the most $10 \%$ of the total support available to the program should be dispensed for such cases.

- An increased number of applications has been received that concern short stays for observing programmes. Should support be given for such cases? The members present were of the opinion that this would only be possible in connection with more extended stays at the host institution.

- Should the current Guideline of only one travel grant per applicant continue to be enforced? The members present thought that this should be so, but also that a sensible decision should be made on the merits of each individual casers

\section{Merger with Commission 46}

A restructuration of Commission 46 (henceforth "Astronomy Teaching and Development") is taking place. This includes the merger of 
- Commission 46 - Teaching of Astronomy

- Commission 38 - Exchange of Astronomers

- WG for the World-Wide Development of Astronomy

- International Schools for Young Astronomers

- Teaching for Astronomy Development

The various programs, to be called "Program Groups (PGs)", will continue their activities under a "Co-ordinating Committee (CC)" within Commission 46. Other PGs may be formed, as needed.

The membership of the new Commission 46 will be the Co-ordinating Committee. The representation of the former Commission 38 on the $\mathrm{CC}$ will be the new "President" and "Vice-President" who will become "Chair" and "Vice-Chair" of the Program Group on the Exchange of Astronomers. They may, as needed, form an Advisory Committee.

The members present took note and agreed to this change that effectively dismantles the current Commission 38, but retains its function within the new scheme.

\section{Election of Officers}

The meeting elected the present Vice-President of Commission 38, R. M. West, as Chair, and C. R. Tolbert, as Vice-Chair of the Program Group on the Exchange of Astronomers. They will discuss the transfer of the functions with the President and Vice-President of the new Commission 46.

\section{Other Business}

No further matters were raised.

The Vice-President closed the meeting at 11:28.

R.M. West

Vice-President of the Commission 